\title{
Considerations on Magnetic Saturation of Cemented Carbides*
}

\author{
Hisashi Suzuki, ${ }^{* *}$ Takaharu Yamamoto** \\ and Kozi Hayashi**
}

\begin{abstract}
Synopsis
Several factors affecting magnetic saturation of the cemented carbides were studied. It was found that the carbon content of the alloys, i.e., the composition of the binding phase was one of the most important factors, although the value of saturation was affected by cobalt and partly by impurity contents. Carbides grain size or addition of the other carbides was considered to have no effects on the saturation values. It was also indicated that the value of the alloys prepared by slow cooling was not changed by subsequent annealing at low temperatures.

(Received September 16, 1966)
\end{abstract}

\section{Introduction}

The magnetic saturation of cemented carbides has been applied to a measure of the amount of free cobalt (or carbide and $\eta$ phase) and impurity content; hence the magnetic measurement has been used for quality control. However, the value of saturation of the two-phase alloys (or the three-phase alloys, if titanium carbide or tantalum carbide is contained), containing a fixed amount of cobalt, represents considerable fluctuations as shown in Fig. $1^{1)}$ and Fig. 2.1) The authors consider that these results are due to the fact that the carbon content in used specimens, namely, the composition of the binder phase $(\gamma)$ was not strictly controlled. Thus, it appears to be not significant that the values decrease with the increase of cobalt or titanium carbide content, as shown in the figures.

The present study aims to show that the value of magnetic saturation of all the cemented carbides can be explained as a function of the composition of the binder phase, if the cobalt content is kept constant.

\section{Specimens and Experimental Procedure}

WC-Co, WC-TaC-Co, WC-TiC-Co and WC-TiC-TaC-Co alloys were used as specimens. Cosiderable changes were made in their carbon and cobalt contents, carbides ratio and impurity (i.e., $\mathrm{Fe}$ and $\mathrm{Ni}$ ) contents. In the specimens containing titanium carbide, the content of titanium carbide was within $17 \mathrm{wt} \%$ in total carbides, leading to the alloys consisting mainly of $(\mathrm{WC}+\beta+\gamma)$ three phases. Specimens were vacuum-sintered under $5 \times 10^{-2} \mathrm{mmHg}$ and at $1350 \sim 1450^{\circ} \mathrm{C}$ for $1 \sim 1.5 \mathrm{hr}$. Annealing treatment of the sintered specimens was also carried out in vacuum at temperature as low as $800^{\circ} \mathrm{C}$. The carbon contents of specimens were determined by chemical analysis. The magnetic saturation of the specimens was measured, and the relationships between the saturation values and the cobalt content, carbon content, carbide grain size, impurity content and addition of the other carbides were investigated. The relationships between the properties of cemented carbides and the composition of the binder phase were frequently reported by the present authors. ${ }^{2 \sim 13}$ ) Therefore, the results of these reports will be referred to in this paper.

\footnotetext{
* This paper was presented at the 1966 Spring Meeting of the Japan Society of Powder Metallurgy. ** Department of Metallurgy, Faculty of Engineering, University of Tokyo, Tokyo.
} 


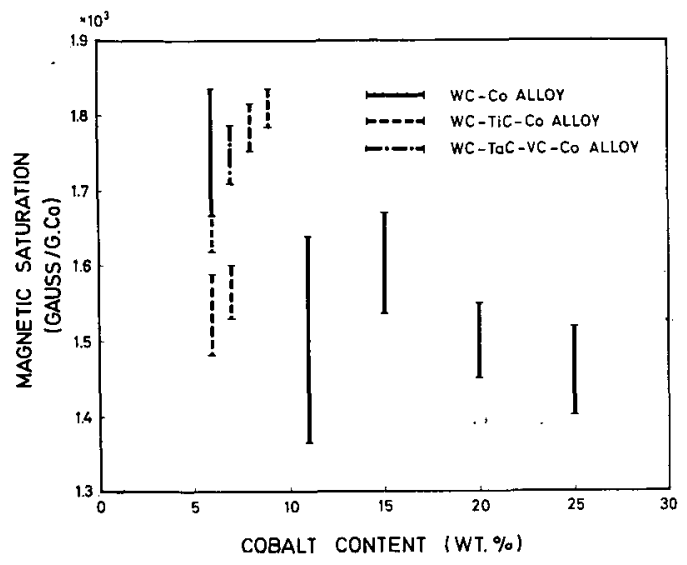

Fig. 1 Magnetic saturation of several kinds of cemented carbides as a function of cobalt content, according to Schwarzkopf and Kieffer. (Ref. 1)

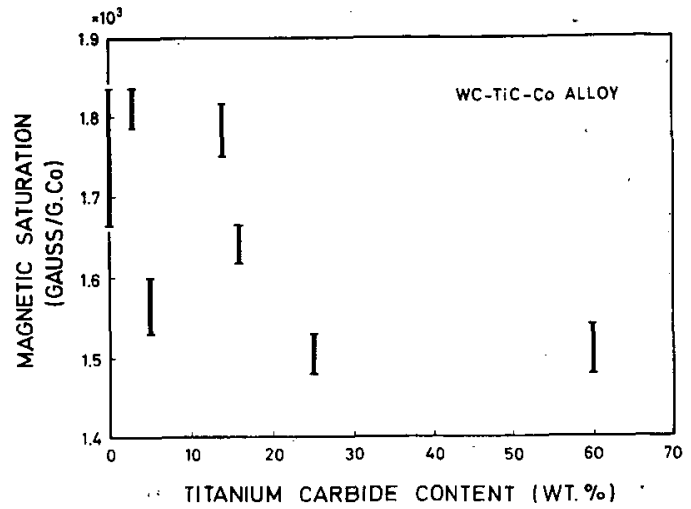

Fig. 2 Magnetic saturation of WC-TiC-Co cemented carbides as a function of titanium carbide content, according to Schwarzkopf and Kieffer. (Ref. 1)

\section{Results and Discussion}

(1) Magnetic saturation of as-sintered alloys.

The effects of carbon content on magnetic saturation of the cemented carbides are given in Fig. 3 (A, B), in which compositions of WC-Co alloys were $10 \%$ and $20 \%$ Co. The figures show that the magnetic saturation of each alloy varies widely with the change of the carbon content, even if the cobalt content is constant. This phenomenon, as previously described, ${ }^{22-13)}$ is due to the change in the composition of binder phase; that is, due to the fact that the content of dissloved tungsten in the $\gamma$ phase varies in the range of $2 \sim 3 \%$ and $9 \sim 10 \%$, depending on the carbon content in $(\mathrm{WC}+\gamma)$ two-phase alloys. Accordingly, the saturation values of alloys having the same binder composition (for example, of alloys with free carbon phase) should increase proportionally with the cobalt content. On the other hand, it is well known that the alloys containing $\eta$ phase show the decrease of the values with the decrease of carbon content, which result from the decrease of cobalt content due to the formation of non-magnetic $\eta$ phase.

As the results, the magnetic saturation of cemented carbides can be expressed as a function of the binder content and its composition. However, the amount of dissolved tungsten in the binder phase may also be controlled by the carbides grain size, assuming that Thomson's equation can be applied in solid binder phase. Accordingly, it is supposed that the saturation values would vary with the grain size. As illustrated in Fig. 4 indicating an example of WC-10\% Co alloy, however, the effects of grain size can be hardly found in the range of these grain sizes.
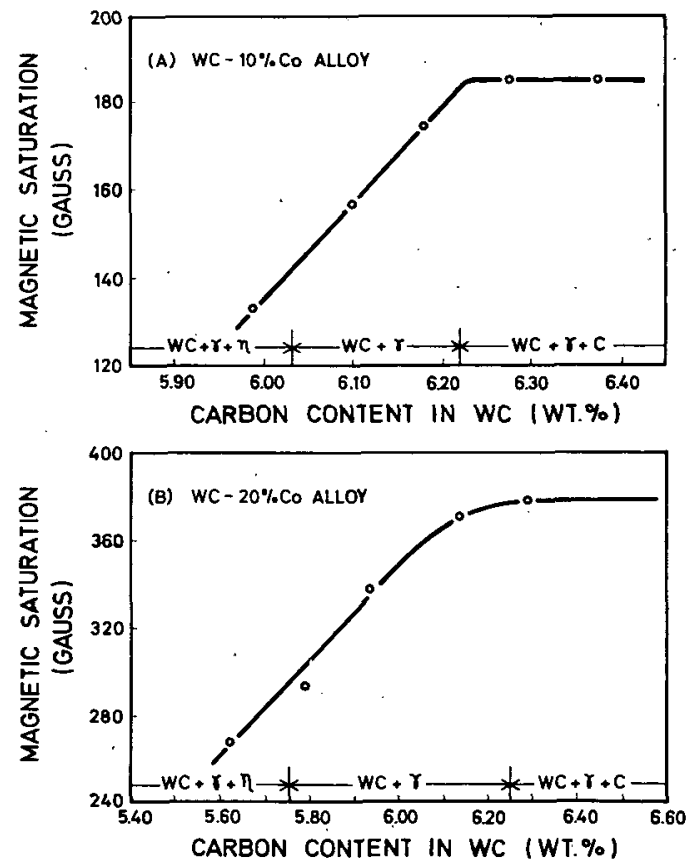

Fig. 3 (A, B) Effects of carbon content on magnetic saturation of $\mathrm{WC}-\mathrm{Co}$ straight alloys. (A) $10 \%$ Co and (B) $20 \%$ Co alloys. 


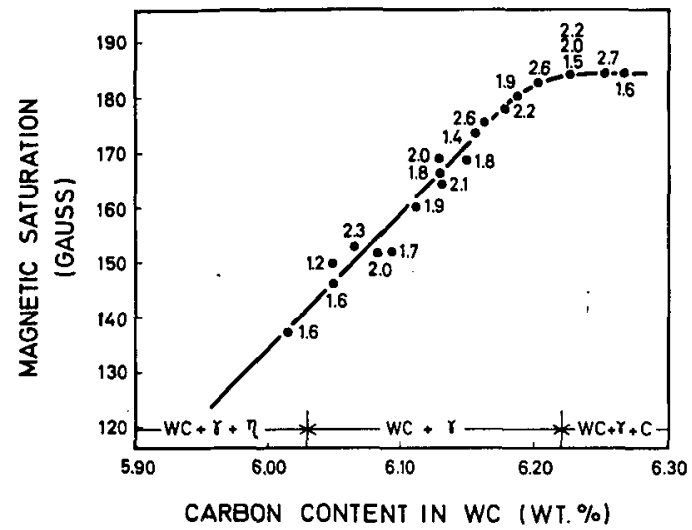

Fig. 4 Magnetic saturation of WC-10\% Co alloys having various carbide grain sizes and carbon contents. Mean grain sizes are shown by the figures in microns.

The magnetic saturation of WC-TaC-Co composition is illustrated in $\mathrm{Fg} .5(\mathrm{~A}, \mathrm{~B})$. It can be seen that the addition of tantalum carbide has no effects on the values of WC-Co alloys. The similar results were obtained in WC-TiC-Co composition, as shown in Fig. 6. In alloys containing titanium carbide, $(\mathrm{WC}+\beta+\gamma)$ three phase region extends with titanium carbide content due to the composition change in the $\beta$ phase. ${ }^{10) 12}$ However, it is shown that the maximum and minimum values of magnetic saturation in the three phase region are identical with those of the straight alloys. The same phenomena as mentioned above are also encountered in WC-TiC-TaC-Co alloys. In WC-TaC-Co alloys having high contents of tantalum carbide, the extension of the three phase range was also observed with increase of tantalum carbide content, ${ }^{13}$ ) but it was much smaller than that of WC-TiC-Co alloys. The reason why the addition of tantalum carbide or titanium carbide does not change the magnetic saturation of cemented carbide may possibly be that they are hardly soluble in the binder phase. This conside-
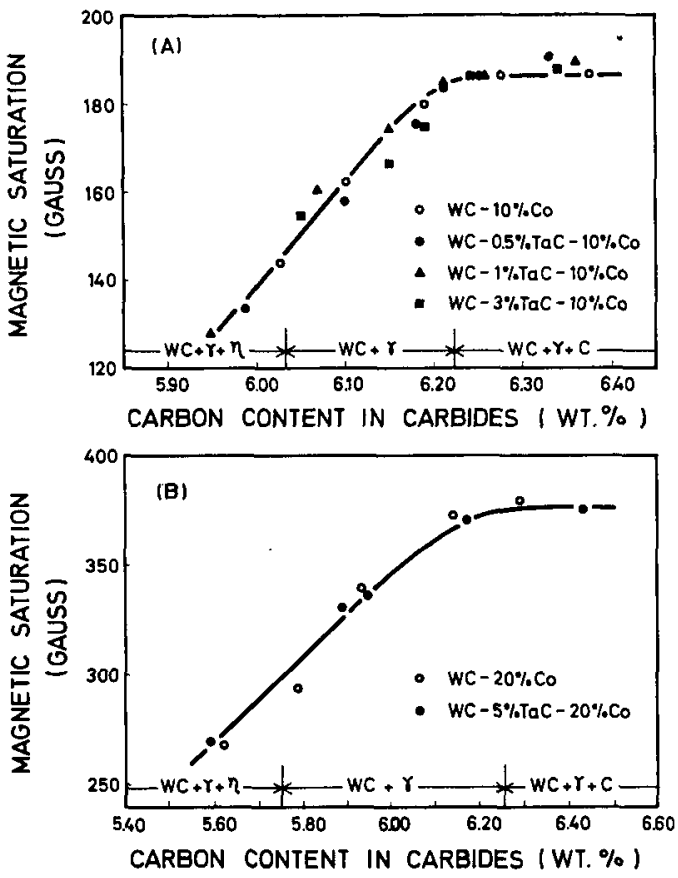

Fig. 5 (A, B) Effects of carbon content on magne. tic saturation of alloys containing tantalum carbide. (A) $10 \% \mathrm{Co}$ and (B) $20 \%$ Co alloys.

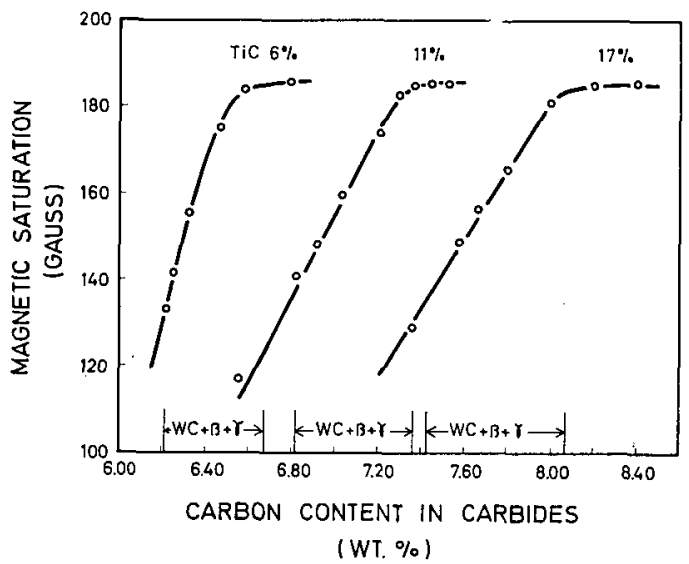

Fig. 6 Effects of titanium carbide content and carbon content on magnetic saturation of $\mathrm{WC}-\mathrm{TiC}-10 \% \mathrm{Co}$ alloys. ration was confirmed to be true by the authors ${ }^{7 / 10) 12}$ by means of X-ray microanalysis of the binder phases.

Impurities introduced from the pot-wall during the ball-mill operation, give harmful effects on the properties of alloys, especially on their mechanical properties. Therefore, it is desirable to know the amounts of impurities. The effects of main impurities, i.e., $\mathrm{Fe}$ and $\mathrm{Ni}$, on the magnetic saturation of the alloys are presented in Fig. 7. The figure shows that the presence of Fe raises magnetic saturation, while Ni reduces it. These tendencies may be natural since Bohr's magnetons of $\mathrm{Fe}$ and $\mathrm{Ni}$ are 2.22 and 0.60 respectively, against $1 . \overline{7} 2$ of $\mathrm{Co}$.

Thus, it is concluded that the fluctuations of the magnetic saturation in Fig. 1 and Fig. 2 are mainly caused by overlooking. an important factor; in order to obtain good results it seems to be necessary to 
pay attention to the nature of the binder phase, which is determined by the carbon content. For example, Fig. 1 and Fig. 2 show a tendency to decrease of the magnetic saturation with the in. crease of cobalt or titanium carbide content, but all of the values in the figures are involved in the range of the values obtained in the present experiment in relation to the carbon content (the range of values is about $1.45 \times 10^{3} \sim 1.85 \times 10^{3}$ Gauss $/ g \cdot C_{0}$ when the alloys consist of two phases, or three phases if tantalum carbide or titanium carbide is contained in the alloys). The magnetic

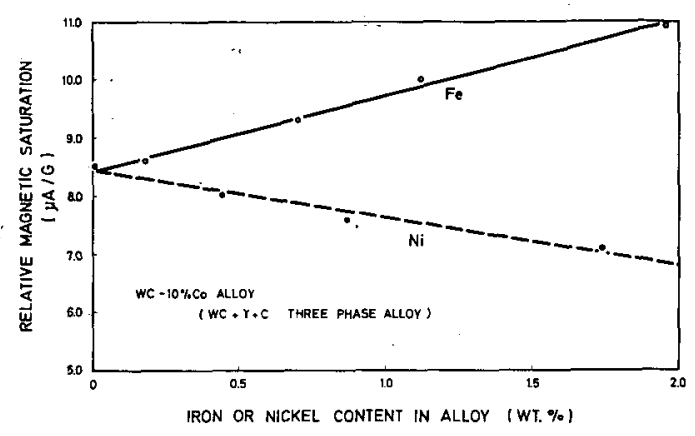

Fig. 7 Effects of iron or nickel contents on magnetic saturation of $\mathrm{WC}-10 \%$ Co alloys. saturation $Z$ of an alloy will be considered to be a function of the following variables; the binder phase content $\left(\mathrm{Co}_{\mathrm{O}}+\mathrm{W}+\mathrm{C}+\right.$ impurities) $\mathrm{y}$, tungsten content $\mathrm{x}$ in the binder phase, carbon content $\mathrm{w}$ in the binder phase and impurities content $v$. Thus, $Z$ can be generally expressed by

$$
z=f\left(\frac{x}{y}, \frac{w}{y}, \frac{v}{y}\right) \cdot y
$$

(2) Effects of low temperature annealing on magnetic saturation

The aging phenomena of WC-Co base alloys caused by a low temperature annealing have been known as follows. In the case of the quenched specimens, the precipitation of WC phase from $\gamma$ phase occurs as reported by J. Hinnüber et al., ${ }^{14)}$ while, in slow-cooled specimens, the $\mathrm{Co}_{3} \mathrm{~W}$ type compound (probably non-magnetic) precipitates. ${ }^{335)}$ In the latter case, it was also known that the formation of $\mathrm{Co}_{3} \mathrm{~W}$ type precipitate is more remarkable in the low carbon alloy containing a large amount of tungsten in $\gamma$ phase, and that the content of tungsten in $\gamma$ phase is reduced to the almost minimum value of $2 \sim 3 w t \%$ (the value of as-sintered alloy of the highest carbon content) during the precipitation, independent of its initial tungsten content.

It will be discussed below how the magnetic saturation of the alloys changes with the $\mathrm{Co}_{3} \mathrm{~W}$ precipitation. As mentioned above, the magnetic saturation of the alloys is given by equation (1). Although the data on the effects of carbon in $\gamma$ phase have not so far been obtained, the effects of carbon are considered to be much less important compared with those of tungsten for the magnetic saturation of the alloys with constant cobalt content. Furthermore, it is also considered that a very small amount of impurities such as iron and nickel give almost no effects on the aging process as well as on the saturation values. Therefore, equation (1) may be rewritten as follows assuming that the binder of the alloy consists only of cobalt and tungsten.

$$
z=f\left(\frac{x}{y}\right) \cdot y
$$

Since $\mathrm{dy} / \mathrm{dx}$ is a constant, which is about $2^{*}$ in $\mathrm{Co}_{3} \mathrm{~W}$ type precipitation, the change of magnetic saturation with tungsten precipitation can be calculated as follows;

$$
-\frac{d z}{d x}=k\left[f\left(\frac{x}{y}\right)-\frac{x}{y} \frac{d f}{d\left(\frac{x}{y}\right)}\right]+\frac{d f}{d\left(\frac{x}{y}\right)}
$$

where $\mathrm{k}=\mathrm{dy} / \mathrm{dx}$. On the other hand, the linear part of curves in Fig. 3 may approximately be expressed as

$$
f\left(\frac{x}{y}\right)=A+B \frac{x}{y}
$$

where $\mathrm{A}$ and $\mathrm{B}$ are material constants. Equations (3) and (4) lead to

* Three atoms of $C_{0}$ are consumed by the precipitation of one atom of $\mathrm{W}$. 
Table. 1 The values of various constants ( $A, B, k$ ), the calculated value of $\mathrm{d} z / \mathrm{dx}$ and the maximum change of the magnetic saturation $(4 \pi \sigma)$ corresponding to the maximum change in dissolved tungsten in $\gamma$ phase (about $8 \%, 10 \% \mathrm{~W}$ minus $2 \% \mathrm{~W}$ ).

\begin{tabular}{c|c|c|c|c|c}
\hline alloy system & $\begin{array}{c}\mathrm{A} \\
\left(\frac{\text { Gauss }}{\mathrm{g} \cdot \mathrm{alloy}}\right)\end{array}$ & $\begin{array}{c}\mathrm{B} \\
\left(\frac{\text { Gauss }}{\mathrm{g} \cdot \mathrm{alloy}}\right)\end{array}$ & $\mathrm{k}$ & $\begin{array}{c}\mathrm{d} z / \mathrm{dx} \\
\left(\frac{\text { Gauss }}{\mathrm{g} \cdot \mathrm{alloy}}\right)\end{array}$ & $\begin{array}{c}\text { maximum change of 4 } \pi \sigma \\
\left(\frac{\text { Gauss }}{\mathrm{g} \cdot \mathrm{alloy}}\right)\end{array}$ \\
\hline WC-10\%Co & 200 & -500 & 2 & -100 & -9 \\
\hline WC-20\%Co & 400 & -1000 & 2 & -200 & -18 \\
\hline
\end{tabular}

$\frac{\mathrm{d} Z}{\mathrm{dx}}=\mathrm{Ak}+\mathrm{B}(=$ constant $)$

By applying material constants $A$ and $B$ which are estimated from Fig. $3(A, B)$, the value of $d z / d x$ and the maximum change of the magnetic saturation corresponding to the maximum change of tungsten content in $\gamma$ phase (from nearly $10 \%$ to 2\%) can be calculated as shown in Table 1. Based on these calculated values, it will be seen that the decrease of magnetic saturation of the cemented carbides may be very little ( $5 \%$ at most), in other words, the value is kept nearly constant.

The experimental results of isothermal annealing at $800^{\circ} \mathrm{C}$ are shown in Fig. 8 (A, B), which illustrates no change in the magnetic saturation in each case. The calculated result may agree with that of the experiment, if the experimental errors and the effects of the carbon content of the binder phase (which is neglected in the calculation) are taken into consideration.

In some papers ${ }^{455}$ already published by the present authors, the relative magnetic saturation, instead of the absolute magnetic saturation, was measured. In the case of as-sintered specimens, the relative value nearly corresponds with the absolute one. In as-annealed specimens the observed sharp decrease of the value is ambiguous. However, the results are very important as they show that the magnetic suceptibility decreases due to the refining of the binder phase, which is caused by the $\mathrm{Co}_{3} \mathrm{~W}$ precipitation on the (001) plane of f.c.c. $\gamma$ phase ${ }^{5}$.

\section{Conclusion}

Specimens of alloys such as WC-Co, WC-TiC$\mathrm{Co}, \mathrm{WC}-\mathrm{TaC}-\mathrm{Co}$ and $\mathrm{WC}-\mathrm{TaC}-\mathrm{TiC}-\mathrm{Co}$ with various carbon contents were used as vacuum-sintered state or subsequently vacuum-annealed state if necessary. The magnetic saturation of as-sintered alloys was measured as a function of the carbon content and the results were discussed relating to the contents of cobalt, carbon, tantalum carbide, titanium carbide and impurities and mean particle size of carbides. The change of the magnetic saturation caused by a low temperature annealing of the alloys was also examined. Main results obtained are as follows;

(1) The carbon content of the alloys (i.e., tungsten content in $\gamma$ phase) highly affects the
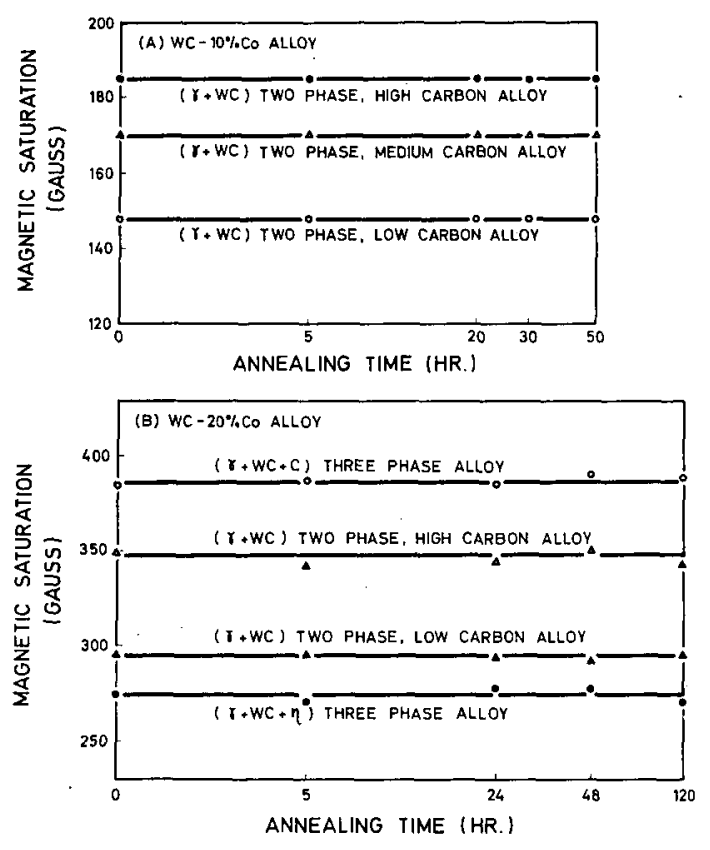

Fig. 8 (A, B) Effects of annealing on magnetic saturation of $\mathrm{WC}-10 \% \mathrm{Co}$ (A) and $\mathrm{WC}-20 \% \mathrm{Co}$ (B) alloys. Annealing temperature, $800^{\circ} \mathrm{C}$. 
magnetic saturation. Therefore, the carbon content is considered to be the most important factor to cause fluctuation in the magnetic saturation (as previously obtained by many investigators). (2) The particle size of the carbides appears to have no effects on the magnetic saturation. (3) Addition of tantalum carbide or titanium carbide to WC-Co alloys does not affect the magnetic saturation, because tantalum carbide or titanium carbide is hardly soluble in $\gamma$ phase. The effects of the impurities such as iron and nickel are significant. (4) The magnetic saturation of low carbon alloys is hardly affected by the annealing to cause $\mathrm{Co}_{3} \mathrm{~W}$ type precipitation. (5) The magnetic saturation of cemented carbide having constant binder content can be obtained without any fluctuation of the values, only if tungsten content of $\gamma$ phase (i.e., carbon content of the alloys) and impurities contents are known.

\section{References}

1) P. Schwarzkopf and R. Kieffer: Cemented Carbides, The Macmillan Comp. (1960), 165.

2) H. Suzuki, M. Sugiyama and T. Umeda: J. Japan Inst. Metals, 28 (1964), 55.

3) H. Suzuki, M. Sugiyama and T. Umeda: J. Japan Inst. Metals, 28 (1964), 287.

4) H. Suzuki, M. Sugiyama and T. Umeda: J. Japan Inst. Metals, 28 (1964), 577.

5) H. Suzuki, M. Sugiyama and T. Umeda: J. Japan Inst. Metals, 29 (1965), 467.

6) H. Suzuki, M. Sugiyama and T. Umeda: J. Japan Inst. Metals, 29 (1965), 974.

7) H. Suzuki, M. Sugiyama, T. Yamamoto, A. Hara and H. Kitano: J. Japan Inst. Metals, 29 (1965), 965.

8) H. Suzuki, M. Sugiyama and K. Hayashi : J. Japan Inst. Metals, 29 (1965), 970.

9) H. Suzuki, M. Sugiyama and T. Yamamoto: J. Japan Inst. Metals, 30 (1966), 367.

10) H. Suzuki, K. Hayashi and I. Kawakatsu: J. Japan Inst, Metals, 30 (1966), 689.

11) H. Suzuki: Trans. Japan Inst. Metals, 7 (1966) 112.

12) H. Suzuki and K. Hayashi: Trans. Japan Inst. Metals 7 (1966) 199.

13) H. Suzuki and T. Yamamoto: J. Japan Inst. Metals, 31 (1967), not yet published.

14) J. Hinnüber and O. Rüdiger : Cobalt, 19 (1963), 57.

\section{第 2 回粉体セミナーテキストの頒布ご案内}

本会に扰きむしは第 2 回粉体セミナーを去る9月開催いたしましたが，同セミナーのテキスト頒布の要 望が多くありましたので，当日参加さ机ていない方にすテキスト（B 5 判150頁）を 1 部1,500円(送料とも) にて配布することになりましたので，で希望の方は本会事務局まで扰申し込み下ざ．

目次

\author{
粉体の充てえと流陲 \\ 粉 体の物性 \\ 分散体の流動持性について \\ 焼結基礎椧 \\ 粉体の等方王縮 \\ 王粉体抽よび焼結体の機械的強さ \\ 鉄鋐石のペレタイジング \\ 塗料用顔料の物性
}

薬品の顆粒および造粒

\begin{tabular}{|c|c|c|c|}
\hline (鹿大·工・教授) & 久 野 & & 洋 \\
\hline (東工大·教授) & 早川宗 & 八 & 郎 \\
\hline （東北大・教授） & 梅 屋 & & \\
\hline （阪大・教授） & 藤 田 & 英 & \\
\hline （東工大・助教授） & 藤 & 進 & \\
\hline (早大·教授) & 葉山 & 房 & \\
\hline (神戸製鋼) & 国 开 & 和 & \\
\hline (関西ペイント) & 重 & & \\
\hline & 品 田 & & \\
\hline （三 & 粟 & 悦 & \\
\hline
\end{tabular}

